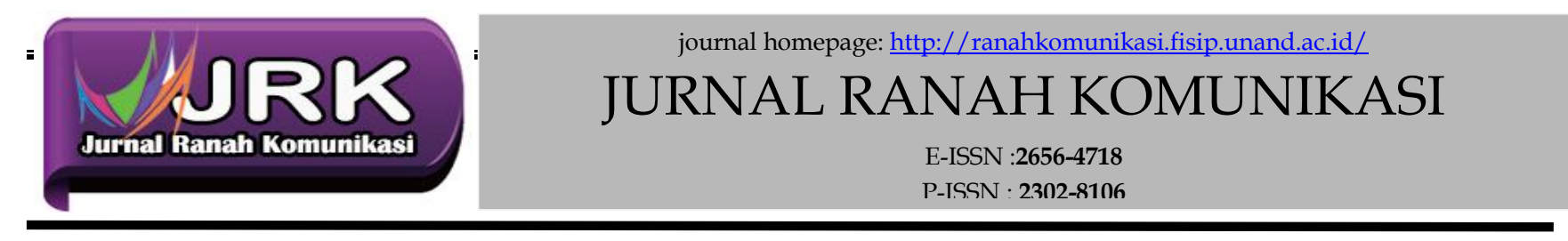

\title{
BAHASA WANITA DAN PRIA PADA KOLOM TANGGAPAN THREAD "PEMERASAN DAN PELECEHAN SEKSUAL OKNUM DOKTER"
}

\author{
Nesthy Kheren Nadia1), Sarmiati2), Ernita Arif3), Sazili4) \\ 1)_Dinas Komunikasi dan Informatika, Pemerintah Daerah Kabupaten Mukomuko, E-mail: nesthy.kheren@yahoo.com \\ 2) Prodi Magister Ilmu Komunikasi, Universitas Andalas, E-mail : mia.unand@gmail.com \\ 3) Prodi Magister Ilmu Komunikasi, Universitas Andalas, E-mail : arifernita@yahoo.co.id \\ 4) Fakultas Keguruan dan Ilmu Pendidikan, Universitas Muhammadiyah Bengkulu, E-mail : sazilisaman@gmail.com \\ ARTICLE INFORMATION

\section{A B S T R A C T}

KEYWORDS:

twitter thread, man and woman language style, pressure and sexual harassment, rapid test SARS$\mathrm{CoV}-2$

\section{CORRESPONDENCE}

Phone: +62811730702

E-mail: nesthy.kheren@yahoo.com

\section{INTRODUCTION}

Pada tanggal 18 September 2020, media sosial twitter sedang dihebohkan dengan sebuah thread yang ditulis oleh seorang wanita dengan akun twitter @listongs yang menyampaikan keluhan terhadap pengalaman yang tidak mengenakan saat akan berkunjung ke Nias, Sumatera Utara. Thread merupakan suatu rangkaian tweet bersambung dan berantai yang tidak cukup ditulis dalam satu kali dipost oleh pengguna media sosial twitter (Mayasari, 2019). Threadnya adalah "Pemerasan dan Pelecehan Seksual oleh Dokter Rapid Test di Bandara Soekarno Hatta, Terminal 3". Thread tersebut mendadak viral dan di komen serta di retweet oleh banyak orang.

Viralnya thread tersebut tidak terbatas dalam media sosial twitter saja. Di instagram pun banyak akun-akun infotainment yang meyebarkannya, mulai dari instas story hingga postingan langsung. Dalam beberapa hari ini media catak nasional, televisi, dan media elektornikpun juga memberitakan mengenai theread yang viral ini sehingga banyak mata yang tertuju untuk mengikuti perkembangan kasus yang saat ini telah diselidiki oleh kepolisian.

Banyaknya pihak yang tertarik dengan thread tersebut membuat akun twitter @listongs 
dibanjiri banyak komentar. Mulai dari komenter dukungan, saran dan pemecahan masalah, katakata kasar, maupun ujaran kebencian (hate speach). Komentarpun diberikan dari berbagai kalangan, ada pria, dan ada wanita. Thread yang di buat oleh akun listongs adalah sebagai berikut :

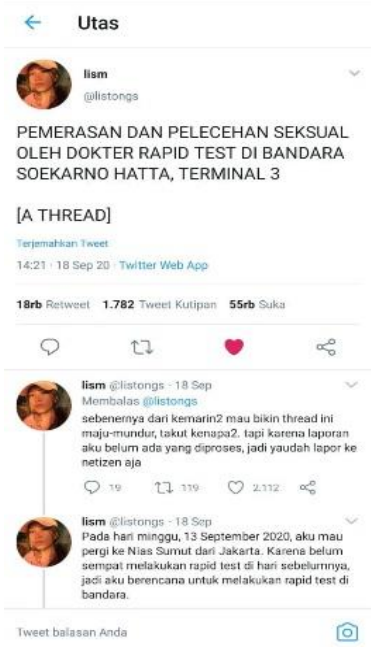

Sumber : twitter.com Gambar 1 Thread yang dibuat oleh akun @listongs

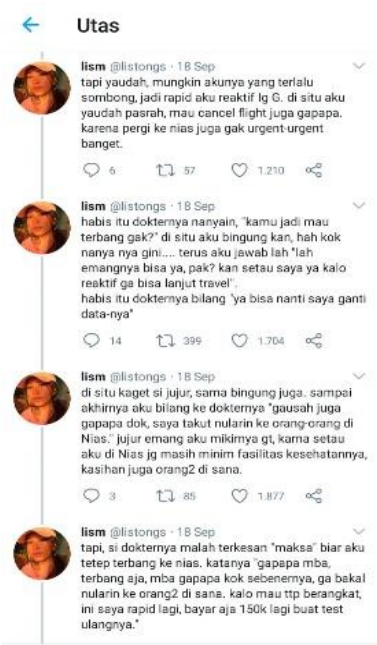

Sumber : twitter.com

Gambar 3 Thread yang dibuat oleh akun@listongs

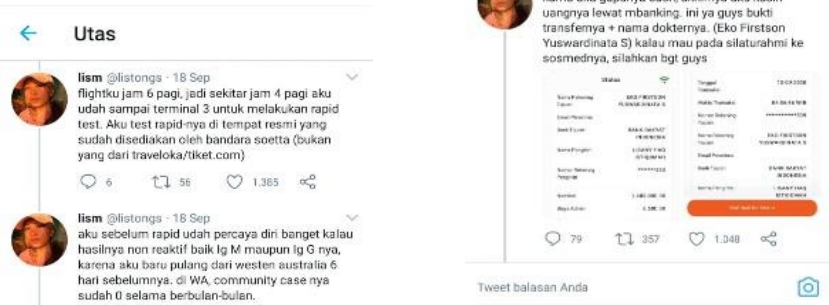

Sumber : twitter.com Gambar 5 Thread yang dibuat oleh akun@listongs

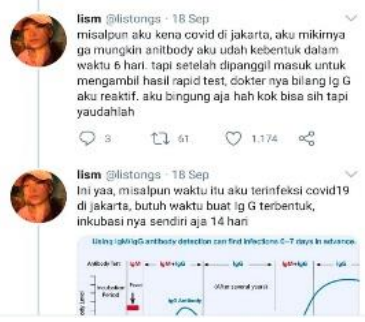

Sumber : twitter.com

Gambar 2 Thread yang dibuat oleh akun @listongs

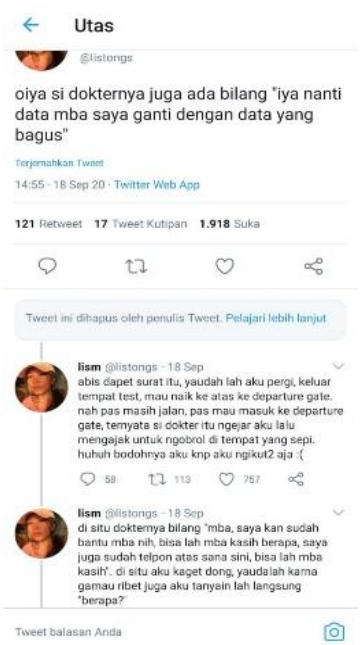

Sumber : twitter.com Gambar 4 Thread yang dibuat oleh akun@listongs

$\leftarrow$ Utas

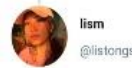

di situ si dokter masih ngikutin aku sampai departure gate, aku cuma bisa diam mematung. takut, hancur, sedih, ga bisa ngapa2in, jangankan untuk mint perolongan, untuk menghindar/melawan aja gak bisa.

TejizTatkan Tweet

15:21. 18 Sep 20-Twitter Web App

48 Retweet 2 Tweet Kutipan 619 Suka

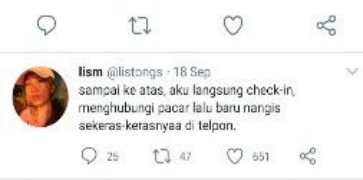

Sumber : twitter.com Gambar 7 Thread yang dibuat oleh akun@listongs

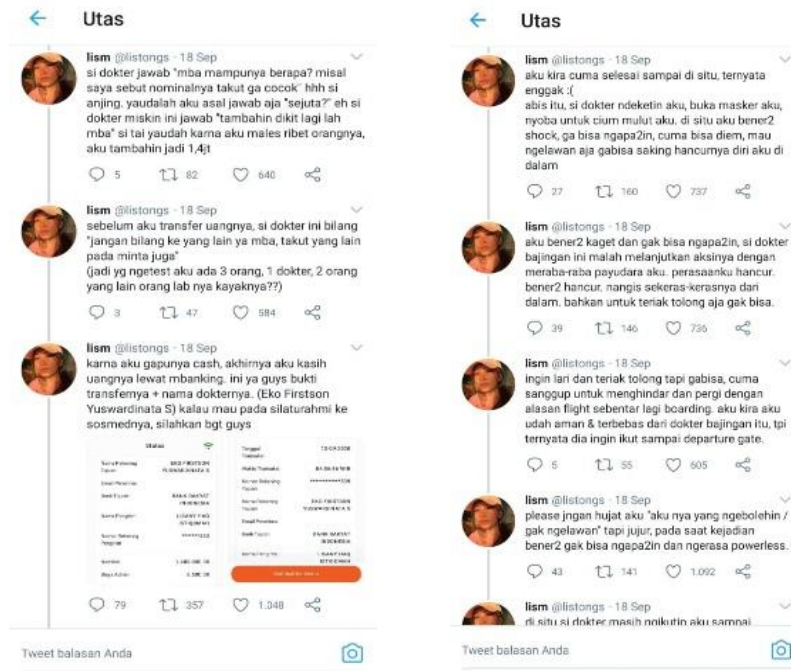

Sumber : twitter.com Gambar 6 Thread yang dibuat oleh akun@listongs semua perasaan bjadi satu. bener-bener

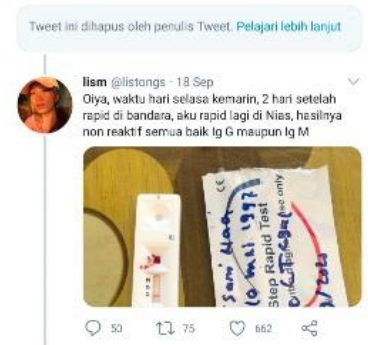

(2)

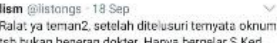

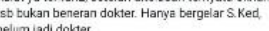
$\begin{array}{lllll}04 & 27 & 113 & 0.54 & 2\end{array}$

(A)

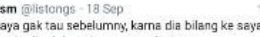

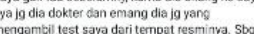

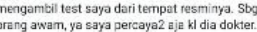

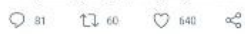

Sumber : twitter.com
Gambar 7 Thread yang
dibuat oleh akun@listongs

Media sosial saat ini menjadi hal yang sangat penting bagi semua orang. Banyak sekali informasi yang disampaikan dalam mediamedia online berasal dari media sosial (Hanana, Anindya, \& Elian, 2020). Dalam media sosial semua bisa terhubung, dari berbagai sifat dan karakter, budaya, serta gender. Media sosial merupakan sebuah media baru. Media baru merupakan berbagai perangkat teknologi komunikasi yang berbagi ciri yang sama yang mana selalu baru dimungkinkan dengan digitalisasi dan ketersediaannya yang luas untuk penggunaan pribadi sebagai alat komunikasi (McQuail, 2011).

Berdasakan teori-teori sosial yang dikembangkan oleh Durkheim, Weber, Marx dan lainnya, dapat disimpulkan bahwa media sosial bisa dilihat dari perkembangan bagaimana hubungan individu dengan 
perangkat media. Karakteristik kerja komputer dalam web 1.0 berdasarkan pengenalan individu terhadap individu lain (human cognition) yang berada dalam sebuah sistm jaringan, sedangkan Web 2.0 berdasarkan sebagaimana individu berkomunikasi (human communication) dalam jaringan antar individu. Dalam Web 3.0 karakteristik teknologi dan relasi yang terjadi terlihat dari bagaimana manusia (users) berkerjasama (human cooperation).

Perubahan utama yang berkaitan dengan munculnya media baru seperti : digitalisasi dan konvergensi atas segala aspek media, interaksi dan konektivitas jaringan yang semakin meningkat, mobilitas dan delokasi untuk mengirim dan menerima, adaptasi terhadap peranan publikasi dan khalayak, munculnya beragam bentuk baru pintu (gateway) media, serta pemisahan dan pengaburan dari lembaga media (McQuail, 2011).

Twitter merupakan selah satu media baru dengan pertumbuhan yang besar dan pesat dengan cepat menarik perhatian pengguna di berbagai dunia, dan banyak digunakan hingga saat ini. Twitter adalah media social dan mikroblog daring yang memungkinkan penggunanya untuk mengirim dan membaca pesan berbasis teks hingga 280 karakter yang dikenal dengan sebutan kicauan (tweet). Twitter didirikan pada bulan Maret 2006 oleh Jack Dorsey, dan situs jejaring sosialnya diluncurkan pada bulan Juli. Dari awal peluncurannya hingga saat ini, twitter menjadi salah satu situs media sosial yang paling banyak dikunjungi di internet sehingga twitter dujuluki sebagai "short message" dalam media sosial.

Untuk berkomunikasi dalam bermedia sosial, sesorang harus menggunakan sebuah bahasa. Definisi bahasa dari segi fungsinyaa merupakan sebuah alat yang dipergunakan untuk saling bertukar pemikiran dengan melalui kesepakatan diantara anggotanya, bahasa dapat dimengerti oleh sesama anggota kelompok dikarenakan adanya kesepakatan dalam memaknai artinya. Sedangkan definisi formal menyatakan bahwa bahasa sebagai semua kalimat yang terbayangkan, yang dapat dibuat menurut peraturan tata bahasa (Rakhmat, 2018)

Toiritikus kontemporer mengatakan bahasa adalah ekstensi perilaku sosial.
Pengucapan bahasa pada dasarnya tergantung dengan kemampuan sesorang untuk membuat berbagai bunyi yang berbeda-beda untuk menghasilkan sebuah kata dengan cara menempatkan lidah ditempat yang berbedabeda (Mulyana, 2010). Menurut Sapir Whorf dalam Ruben \& Stewart (2013) bahasa adalah tidak hanya alat reproduksi untuk menyuarakan ide-ide, melainkan juga merupakan sarana pembentukan ide.

Pengalaman seseorang tidak mungkin lepas dari pengaruh bahasa. Bahkan kategori pria dan wanita adalah hasil dari pembentukan secara linguistik. Sejaklahir kita diarahkan untuk membedakan duajeniskelamin yang berlainan, yaitu wanita dan pria. Kemudian kita melakukan banyak kegiatan untuk terus melihat hanya kedua jenis kelamin itu" (Littlejohn \& Foss, 2011)

Dalam kehidupan sosial maupun dalam bermedia sosial banyak terdapat perbedaan yang ditunjukan antara bahasa Wanita dan bahasa Pria. Laki-laki dan perempuan memiliki karakter bahasanya masing-masing. Wanita dan pria merupakan mahluk hidup biologis yang diciptakan Tuhan. Sebagai manusia, tentunya wanita dan pria memiliki banyak sekali perbedaan, mulai dari perbedaan fisik biologis, maupun psikisnya. Dikarenakan psikisnya yang berbeda, maka bahasa yang digunakan oleh pria dan wanita pun berbeda. Gender digunakan untuk menjelaskan perbedaan peran antara wanita dan pria yang bersifat bawaan sebagai mahluk hidup yang ciptakan Tuhan. Wanita dan pria memiliki berbagai macam perilaku komunikasi yang berbeda. Banyak ilmuan yang percaya bahwa wanita dan pria belajar untuk berbicara dengan cara berbeda. Wanita dan pria juga telah menginternalisasi norma yang berbeda untuk sebuah percakapan.

Jumlah kata yang diucapkan oleh wanita cenderung lebih banyak dari jumlah katayang diucapkan oleh pria. Tema pembicaraan yang sering dilakukan oleh wanita dan pria-pun memiliki banyak perbedaan. Pria biasanya membahas mengenai hobi, berita fakta, olahraga, dan information technology. Sedangkan wanita lebih memilihuntuk membicarakan mengenai hal-hal pribadinya, entertainment, dan fashion. Perbedaan tempat, situasi, dan budaya akan membuat perbedaan dalam penggunaan bahasa sehari-hari. 
Penggunaan bahasa pria bukan lebih baik dari pada bahasa wanita dan sebalinya, bukan pula bahasa wanita lebih baik dari pada bahasa pria. (Zulkarnain \& Fitriani, 2018). Faktor yang turut menyebabkan dorongan untuk menggunakan bahasa berbeda sesuai peranan dalam masyarakat adalah faktor sosial dan ekonomi.

Dalam kebanyakan budaya, perilaku komunikasi individual digunakan baik oleh pria maupun wanita. Misalnya pria dan wanita akan tersenyum untuk menunjukan kesenangan, atau meninggikan suara untuk menunjukan kemarahan. Menurut suatu perkiraan, perilaku pria dan wanita saling melengkapi sebanyak 99\% dari seluruh waktu komunikasi mereka. Disisi lain, ada ilmuan yang percaya bahwa pria dan wanita belajar berbicara secara berbeda, bahwa pria dan wanita telah menginternalisasi norma yang berbedauntuk percakapan. Pria cenderung mengadopsi gaya yang lebih kompetitif dalam percakapan, sementara wanita cenderung mengadopsi gaya yang lebih koperatif. Karena gender adalah konstruksi sosial dari sebuah maskulinitas dan feminitas dalam suatu budaya, perbedaan prilaku komunikasi laki-laki dan wanita menjadi sangat mungkin terjadi secara budaya. Menurut Brent dan Lea dalam Naibaho (2016) beberapa peneliti mencatat ada beberapa perbedaan diantara bahawa wanita dan pria, diantaranya adalah karakteristik leksikal dan fonologis, saat memulai sebuah percakapan, memelihara percakapan dan mengajukan pertanyaan, dan berargumentasi.

Wanita dan pria mempunyai kosakata berlainan, hal tersebut disebabkan oleh perbedaan dalam cara mereka bersosialisasi. Terutama cara pandang dan minat mereka yang berlainan terhadap unsur kehidupan. Deborah Tannen mengatakan dalam Amri (2009) bahwa perbedaan antara pria dan wanita merupakan hal alamiah. Biasanya arah pembicaraan wanita menjurus kearah hubungan yang berkesinambungan dengan lawan bicaranya. Sedangkan cara pria berinteraksi cenderung bersifat kompetisi. Louann Brizendine dalam Zulkarnain \& Fitriani (2018) mengatakan dalam bukunya Female Brain bahwa terdapat perbedaan yang sangat jauh diantara wanita dan pria dalam jumlah kata yang diucapkan sehari-hari. Biasanya wanita menggunakan sebanyak 20.000 kata setiap harinya, sedangkan pria jauh lebih sedikit penggunaan katanya dari pada wanita, yaitu sekitar 7000 kata. Selain itu, Blum memberikan contoh dalam Yunita et al (2011) misalnya pria cenderung berfikir lebih objektif dan seorang perempuan cenderung emosional,.

Tedapat juga perbedaan dalam aturan penggunaan bahasa yang berhubungan dengan bentuk dan makna yang dikaitkan pada unsur konteks, komunikan dan komunikatornya, hingga kondisi terjadinya pembicaraan antara bahasa wanita dengan bahasa pria. Wanita menggunakan lebih banyak pembicaraan ekspresif dan berorientasi pada hubungan dengan komunikator ataupun komunikan. Interupsi wanita bukan untuk mengendalikan seperti yang dilakukan oleh pria, bukan menantang atau mengancam lawan bicara, walaupun mungkin hal tersebut mungkin terjadi namun cenderung untuk menekankan dan menegaskan pembicara. Sementara itu, pria menggunakan lebih bayak pembicaraan instrumental (untuk mempengaruhi dan mengendalikan orang lain), melaporkan informasi, memecahkan masalah, dan menyelesaikan tugas melalui pertukaran informasi. Dalam konteks ini kata-kata yang diucapkan wanita kurang lugas dari pada apa yang diucapkan pria. Bahasa wanita cenderung menekankan kepatuhan, persetujuan, atau kepercayaan kepada pendengar (Mulyana, 2010)

Menurut James Holmet dalam (Hidayati, 2016), ada beberapa alasan kenapa laki-laki dan perempuan menggunakan bentuk bahasa yang berbeda, yaitu status sosial, peranan perempuan dalam masyarakat, status sosial perempuan sebagai kelompok subordinat, fungsi ujaran yang menunjukkan maskulinitas.

Banyak terdapat perbedaan penggunaan bahasa dari wanita dan pria, melihat hal tersebut peneliti tertarik untuk melihatnya lebih dalam lagi. Penelitian ini dilakukan untuk melihat bagaimana perbedaan gaya bahasa wanita dan pria yang ditunjukkan dalam kolom komentar pada thread "Pemerasan dan Pelecehan Seksual oleh Dokter Rapid Test di Bandara Soekarno Hatta, Terminal 3" di media sosial twitter. Yang menjadi pertanyaan penelitian untuk dijawab melalui riset ini adalah dimana letak perbedaan gaya bahasa wanita dan pria dari komentar-komentar yang dikirimkan oleh pengguna twitter pada thread tersebut. 


\section{METHOD}

Penelitian ini akan mengkaji teks yang terdapat dalam kolom komentar thread "Pemerasan dan Pelecehan Seksual oleh Dokter Rapid Test di Bandara Soekarno Hatta, Terminal 3" di media sosial twitter. Model pendekatan penelitian yang dipakai adalah kualitatif content analysis. Penelitian ini diadakan pada saat terjadinya pandemi Sars-cov-2 atau yang dikenal dengan pandemi covid-19 sehingga analisis isi merupakan salah satu pendekatan yang efektif digunakan untuk menghindari kerumunan dan menerapkan pembatasan sosial bersekala besar. Analisis isi dingunakan untuk memperoleh keterangan dari isi komunikasi yang disampaikan dalam bentuk lambang.

Analisis isi dapat digunakan untuk memperoleh penjelasan dari sebuah komunikasi yang disampaikan dalam bentuk lambang. Hal yang dapat dianalisis adalah semua bentuk komunikasi, seperti surat kabar, buku, puisi,cerita, lukisan, pidato, surat, peraturan perundang-undangan, musik, teater, dan sebagainya (Rakhmat \& Ibrahim, 2017).

Data kualitatif melihat perilaku yang tidak dihitung untuk mengetahui hubungannya. Menurut Zulianti Komalasari dalam Utami \& Hermanu (2020) metode kualitatif merupakan metode yang digunakan untuk meneliti sampel tertentu. Biasanya data disajikan dalam bentuk gambar dan kata-kata. Analisis dilakukan terhadap teks komentar pada threat sebagai sumber data utama dalam penelitian ini. Sebelum mulai menganalisis, peneliti terlebih dahulu memilih dan melakukan pengelompokkan komentar-komentar dari berbagai pengguna twitter dalam thread tersebut. Pengelompokkan dilakukan menurut gender pemilik akun dan isi yang dibuat oleh akun tersebut. Setelah dikelompokkan maka akan dilihat bagamana hubungannya. Apakah ada hubungan antara gender pria dan wanita dalam pemilihan bahasanya saat berkomunikasi di media sosial. Bagiaimana pemilihan kosakata yang digunakannya dah apa hal yang diminati dalam memberikan komentar dalam threat tersebut.

\section{RESULTS AND DISCUSSION}

Pada bagian pembahasan ini dikemukakan hasil yang diperoleh setelah menganalisis beberapa komentar yang terdapat dalam kolom komentar thread "Pemerasan dan
Pelecehan Seksual oleh Dokter Rapid Test di Bandara Soekarno Hatta, Terminal 3" di media sosial twitter, baik komentar yang ditinggalkan pemilik akun pria dan maupun wanita. Hasil analisis tersebut dideskripsikan sebagai berikut :

\section{Komentar yang Diberikan Oleh Akun Wanita.}

Pada kolom komentar yang diberikan oleh pemilik akun wanita terlihat bahwa disana banyak terdapat komentar yang mengandung unsur kata-kata yang menggunakan perasaan, seperti komentar yang diberikan oleh pemilik akun@ @urisetiowati yang di tweet pada tanggal 27 September 2020 yang berisi : “Alhamdulillah udah ketangkep tuh orangnya, aku salut sama kamu mba, kebanyakan cewek korban pelecehan gak berani speek up." Dilihat dari komentar tersebut, dapat ditarik kesimpulan bahwa wanita tersebut menggunkan emosi dan perasaannya dalam mengomentari thread yang di buat oleh akun@ @listongs._akun@ rurisetiowati mengungapkan rasa empatinya dan rasa salutnya karena sebagai korban pemilik akun berani mengungkapkan kebenarannya dari pada memendam perasaannya sendiri. Pemilik akun @ CitraCamellajuga mengungkapkan emosi dan perasaannya ditunjukan dengan tweet berikut ini : "Thx mbak, udh speak up. Please bagi wanita manapun kamu, jika kamu pernah dilecehin kaya gini, tolong, speak up ! Ga mesti di twitter, di real life bisa.. Inget, kamu ga akan dihakimi karna perbuatan bejat seseorang.. I love you girls".

Pembicaraan hubungan yang berpusat pada perasaan korban pemerasan dan pelecehan seksual tersebut ditujukan menunjukan keinginan untuk lebih memahami perasaan orang lain. Gaya bicara hubungan tersebut juga menunjukan ciri-ciri dari daya respon yang tinggi pada bahasa wanita dikarenakan peduli terhadap orang lain.

Wanita kurang percaya diri sehingga menggunakan kata-kata penguat (intensifiers) Hal itu dilakukan untuk menutupi rasa ketidak percayaan dirinya dalam menyampaikan argumentasi. Terlihat dari sebuah komentar yang ditinggalkan oleh pemilik akun @ stroberiandcigs yang di tweet pada tanggal 19 September 2020. Berikut "ini kalo kasusnya begini, pelaku bisa kehilangan gelar dokternya ga si? kan sudah melanggar kode etik." Kalamiat-kalimat tanya 
untuk persetujuan ini banyak sekali digunakan pemilikakun wanita. Dalam tweet ini kekurangpercayaan diri wanita juga diekspresikan lewat kata-kata penguat "ga si?". Selain itu, kata "so, very," juga merupakan contoh dari intensifier. Jenis kata seperti ini dianggap merupakan karakteristik dari bahasa perempuan karena kata ini mengandung sisi emosional yang erat kaitannya dengan tuturan seorang perempuan.

Ada juga tweet yang menyampaikan pengalamannya sebagai bentuk simpati sebagai sesama wanitayang terlihat dari tweet oleh akun Sthevannie LL Cardin @ capekmikirUnameyang ditweet pada tanggal 20 September 2020 yang berisi : "jangan pake bilang, "kok ga teriak?" , "kok diem?" , "pasrah, lo nikmatin ya?" respon setiap orang berbeda ${ }^{2} \mathrm{dlm}$ posisi kaya gini, ga semua bakal lgsg nunjukin perlawanan fisik. gue pernah dulu pas ketiduran hampir di lecehin sama temen sekampus, pas bangun lgsg gue tendang anu ny". Hal yang sama juga disampaikan pemilik akun @filzazubaidi yang ditweet pada tanggal 18 September 2020 yang berisi " Please ya jngn ada yg blg kenapa mau? Ko diem aja? Knp gak teriak? Kalian gak disana, org pasti shock \& refleks setiap org ketika shock itu beda2. Ada yg teriak, diam seribu bahas, nangis, sampe pingsan. Fokus ke pelecehannya. Semoga mendapat keadilan yang seadil2nya ya mba".

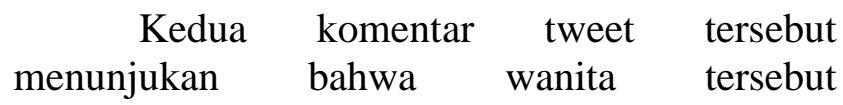
menceritakan pengalamannya yang bertujuan untuk menjaga perasaan dan memelihara hubungan dengan orang lain, dalam hal ini adalah pemilik akun @listong yang menjadi korban pemerasan dan pelecehan seksual. Salah satu komunikasi wanita ditandai dengan kesederajatan. Maksudnya disini adalah untuk mengutarakan persamaan pengalaman. Dengan adanya persamaan pengalaman tersebut, wanita lebih mudah memahami perasaan orang lain. Dalam beberapa hal menunjukan bahwa perempuan lebih banyak kosakata mengenai permasalahan yang membuat mereka sangat tertarik dan permasalahan yang pernah mereka alami sendiri.

Dari banyaknya komentar sesama wanita yang menggunakan perasaan dan mengutarakan pengalaman agar bisa memahami dan berempati kepada sesama wanita, ada satu komentar yang banyak ditolak olah wanita-wanita yang lainnya. Komentar itu berasal dari akun@awwkarin24 yang diposting pada tanggal 19 September 2020 yang berisi "Kok kmu diam aja ya mbak? Pnya mulut, tangan, kaki bukan nya di lawan. Apa kmu menikmati ya?" Kata-kata dari akun tersebut sangat jarang diucapkan oleh seorang wanita. Banyak sekali wanita lainnya yang kontra dengan komentar tersebut yang tidak menunjukan rasa simpati dan empati kepada sesama wanita yang sedang mendapatkan musibah diperas dan dilecehkan oleh seorang oknum dokter rapid test. Selain akun wanita yang menolak komentar wanita tersebut, juga ada akun pria yang menghujat komentar wanita tersebut yang berkata bahwa wanita itu tidak berfikir dulu ketika berbicara dan menilai pengalaman orang lain di media sosial.

Kalimat yang menggunakan ekor tanya juga banyak di gunakan oleh akun wanita, seperti yang diunggah oleh akun @ rosepink89 pada tanggal 21 September 2020yang berrisi "yaku jadi gak yakin kamu reaktif beneran hasil rapid testnya. Kayaknya direkayasa deh sama di dokter kurang ajar ituu. kalo reaktif kok mau nyium? gak takut ketularan? Hmm" dan yang kedua adalah komentar dari akun @ suryaningtimoty yang dibuat pada tanggal 19 September 2020 yang mengatakan bahwa "inikah pahlawan yg kita agungkan?? Jika bener hmmmm".

Kalimat yang menggunakan ekor tanya dengan kalimat tanya merupakan dua kalimat yang berbeda. Kalimat dengan ekor tanya adalah suatu ungkapan yang terdapat di akhir kalimat untuk memberikan penekanan, biasanya hal ini digunakan untuk mendapat persetujuan atau untuk memastikan suatu informasi. Kalimat dengan ekor tanya juga digunakan ketika seorang penutur menyatakan sesuatu, namun ia merasa kurang percaya diri dengan apa yang ia sampaikan. Selain itu, kalimat dengan ekor tanya merupakan salah satu cara yang digunakan seseorang sebagai alat untuk kesantunan, ekspresi yang menunjukkan ketidakyakinan, sebagai alat kesopanan yang positif, memperhalus tuturan direktif atau kritik, dan alat untuk memaksa.

Pemilihan kata-kata yang tanpa makian dan kata-kata kasar merupakan salah satu ciri dari bahasa wanita, salah satunya ditunjukkan oleh pemilik akun @Wied77518018 yang 
menuliskan tweetnya pada tanggal 19 September 2020 yaitu "Maaf..... ketika dia berani (maaf) mencium, sepertinya patut diduga dokter itu bohong dan sdh memalsukan hasil rapid. Masak dia berani mengambil resiko jika anda benar2 reaktif ? Hal yang sama juga diungkapkan pemlik akun dengan nama@yudistiravb yang di tweet pada tanggal 19 Sptember2020 yang berisi : "Big Sympathy for you.. Be Strong and Be Brave to speak up the truth.. Don't worry as the Mighty God Always see and know the truth.. And all that you feel inside.. Don't let that annoying talks of the stupids disturb you... Takecare..." Pemilihan kata yang sopan merupakan salah satu ciri-ciri dari karakteristik bahasa wanita yang sangat dominan. Penggunaan bentuk tuturan yang sangat santun dianggap sebagai sesuatu yang sudah sepantasnya dilakukan oleh wanita. Seorang wanita dianggap memiliki pemilihan bahasa dan tuturan yang lebih sopan dari pada bahasa dantuturan yang digunakan oleh pria.

Selain hal tersebut,ternyata ada juga wanita yang menggunakan kata-kata makian atau kasar. Tetapi kata-kata tersebut ditujukan kepada pelaku pemerasan dan pelecehan seksualnya. Hal ini ditunjukan oleh tweet dariakun @ caramell yang posting padatanggal 19 September 2020 "Kaya gini contoh laki² yang hidup selalu mikirin $\mathrm{k}^{*} \mathrm{nt}^{*} \mathrm{l}^{\prime}$. Lalu ada juga komentar dari akun@mallasari02 yang di post pada tanggal 24 September 2020. "parah sih ini,rapid di jadiin bisnis terus seenaknya itu dokter bego lakuin hal menjijikan.”. adanya tibul komentar dari akun wanita dengan kata-kata makian dan kasar dikarenakan kebencian wanita kepada pelaku pemerasan dan pelecehan seksual tersebut. Wanita turut merasakan perasaan wanita yang menjadi korban pemerasan dan pelecehan seksual.

Penggunaan kata-kata kasar pada wanita bisa terjadi dikarenakan beberapa hal. Salah satu yang membuat itu terjadi dikarenakan pengaruh lingkungan sosial dimana tempat wanita itu dibesarkan. Bisa jadi dari lingkungan keluarga, lingkungan pergaulan teman-teman sebaya, atau dari lingkungan tempat tinggal yang berada disekitar wanita tersebut. Komunikasi bisa membuat seseorang beradaptasi dengan orang lain dan lingkungannya. Menciptakan dan menafsirkan pesan sebagai pribadi dan sebagai bagian dari hubungan, kelompok, organisasi, dan masyarakat adalah untuk mengaitkan diri dengan keadaan dimana kita berada didalamnya.

\section{Komentar yang Diberikan dari Akun Pria}

Banyak sekali akun pria yang mengomentari thread dari akun tweeter @listongs ditemukan beberapa karakteristik yang berbeda diantara akun pria dan wanita yang berkomentar di thread tersebut salah satunya ditunjukan oleh pemilik akun @kennol61 yang ditulis pada tanggal 20 September 2020, yaitu "ini salah satu akibat negatif dari kebijakan BNPB yg merugikan. Abuse oleh petugas, mereka bisa atur hasil rapid test untuk nakut $2 \mathrm{i}$ masyarakat, memeras, bahkan pelecehan sexual. Apapun hasil rapid test tdk berguna $\mathrm{dlm}$ menentukan penularan. Pikirkan baik2. Lalu solusinya apa? .1. Merujuk ke WHO/CDC, atau negara2 lain saja. Kita jgn buat yg aneh2. .2. Administrative and thermal scan screening. .3. Physical distancing di Bandara dan pesawat. Kini seat pesawat masih diisi seperti biasa. .4 HARUSKAN pakai masker standard dll." Dan juga ada salah satu komentar pada tanggal 18 September 2020 dari akun @alvdroosevelt yang mengatakan bahwa "Cuman saran, jikalau ada pelecehan sexual seperti ini, sebaiknya korban lapor polisi dulu, jangan langsung tulis di media sosial. Kenapa ? Karena ketika ada nama orang dicatut/instasi dicatut/profesi/lembaga mbak nya bisa kena dan disangkakan pasal pencemaran nama baik dan ITE"

Akun pria lebih banyak yang berkomentar mengenai persoalan yang ada dan langsung memberikan solusinya. Saat akun wanita melakukan pembicaraan hubungan bersifat pada perasaan dan memelihara hubungan dengan orang lain, akun pria melakukan pembicaraan laporan berpusat faktual tentang apa yang sedang berlangsung, dan pria cenderung mengungkapkan secara "blak-blakan". Pria menggunakan bahasa yang rasional dalam mengungkapkan sesuatu dan biasanya kurang melibatkan perasaan dalam bahasa yang mereka gunakan.

Pria lebih mudah mengutarakan kata-kata yang menurutnya sebagai humor. Contohnya adalah pada komentar yang diberikan oleh akun @dotan_dot yang di tulis pada tanggal 19 September 2020 yang berisi "Mungkin dokternya cakep jd cuma bs terdiam.. *keep 
calm *justKid". Hal tersebut dianggap sebagai sebuah lelucon oleh seorang pria, tetapi lelucon yang dianggap lucu oleh pria tersebut terkadang tidak dianggap lucu oleh wanita, bahkan pada suatu kasus wanita terkadang tersinggung dengan lelucon yang disampaikan oleh pria. Hal itu dikarenakan wanita kurang memiliki rasa humor, wanita kurang pandai menyampaikan lelucon dan sering tidak paham lelucon yang disampaikan pria.

Pria juga cenderung untuk menarik kesimpulan tersendiri dari sebuah pesan yang disampaikan olehorang lain. Hal tersebut ditunjukan dari sebuah komentar yang berikan oleh akun@ReynardAde yang dikirim pada tanggal 19 September 2020 yang berisi "Intinya diam dirumah menyelamatkan kita.. " dan hal yang sama juga di tunjukkan oleh pemilik akun @GuruhSetyaBudi yang di tulis pada tanggal 19 September 2020 yaitu "Hasil test nya reaktif, tapi si kampret berani cium2 ? Ga takut tertular covid atau emang si kampret dah sadar sebenernya covid tuh ga seberbahaya diberita2 ??" Komentar tersebut menunjukan bahwa pria tersebut menarik kesimpulan yang berlawanan dengan yang dikatakan di berita bahwa covid-19 itu berbahaya. Pria cenderung terlibat dalam pembicaraaan laporan yang berpusat pada informasi faktual tentang apa yang sedang berlangsung walaupun hal itu belum tentu benar dan seolah memaksakan kehendaknya agar yang lain setuju dengan apa yang dipikirkannya.

Salah satu ciri dari bahasa pria yaitu menginformasikan sesuatu, berikut ini adalah beberapa contoh komentar dari akun pria yang menunjukan ciri-ciri tersebut.yang pertama adalah komentar dari akun @dharukusumahady pada tanggal 20 September 2020 yaitu "Barusan buka IG \& ternyata teman saya pramugari salah satu maskapai kenamaan juga baru aja speak up lewat story tentang pelecehan dari orang yang sama. Wah, parah sih ini orang”. Yang kedua adalah komentar yang dibuat oleh akun @ listyo_gembong pada tanggal 30 September 2020 yaitu "Mbak, kalau berkasnya naik ke sidang, semoga tetap tabah ya menjalani persidangan, pasti akan dipanggil sebagai saksi korban, khan. Semoga banyak temen-teman sekitar Jakarta yg akan beri dukungan. Abuse of power gini sdh bisa diprediksi dari awal akan diberlakukan new normal". Dan yang ketiga adalah sebuah komentar yang berisi mengenai informasi dan pengalamannya pada petugas rapid tes pada bandara terminal 3 yang datang dari akun@AsepSuwarno77 pada tanggal 19 September 2020 yang berisi "Sempet jg bingung, kemarin sy mw ke Jambi naik dari terminal 3 jg, Petugas nanya kapan di tes, sy bilang kemarin pagi, Dia bilang tdk bs hrs hasil hr ini.. Sy bilang, sy mau di test $\mathrm{lg}$, tp tlg bikin tulisan yg besar "hasil test kemarin tdk berlaku" Dia diem sebari jamedud..."

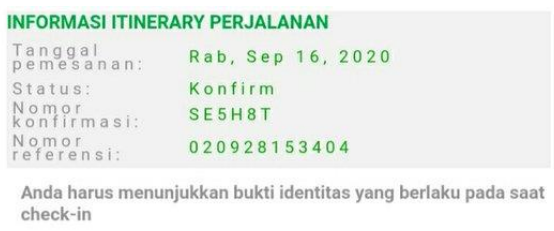
check-in

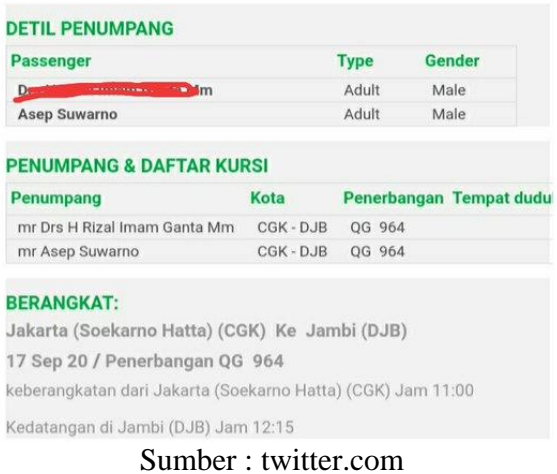

Gambar 9. Bukti yang di upload akun @ AsepSuwarno77

Pada komentar pertama dari akun @dharukusumahady memberikan infromasi mengenai pengalaman orang lain yaitu seorang pramugari yang juga mengalami hal yang tidak mengenakan dari oknum petugas rapid test tersebut. Yang kedua dari akun @listyo_gembong menunjukan bahwa kedua akun tersebut memberikan informasi mengenai hal-hal apa yang akan dialami oleh korban pemerasan dan pelecehan seksual tersebut setelah berkasnya naik dan dilakukan persidangan nanti, selain itu akun @listyo_gembong juga memberikan dukungan agar korban tetap tabah dalam menghadapi harihari persidangan nanti. Yang ketiga datang dari akun@AsepSuwarno77, akun tersebut memberikan informasi bahwa pada hari sebelumnya juga memiliki pengalaman yang tidak baik dari petugas rapid test di bandara. Pada awalnya petugas tersebut mengatakan bahwa hasil rapid test yang dilakukannya pada hari sebelum keberangkatan adalah tidak berlaku lagi,tetapi setelah memberikan argumentasi akhirnya hasil testnya diterima. 
Pada akun@AsepSuwarno77 pada dasarnya akun tersebut menceritakan pengalaman. Ketika akun wanita menertakan pengalaman, bahasa yang digunakan adalah agar terbentuk kedekatan dari segi emosi dan bisa merasakan empati kepada korban pemerasan dan pelecehan seksual, tetapi ketika pengalaman diceritakan oleh akun pria, maka pengalaman tersebut menggunakan gaya bahasa informatif yang mengesankan bahwa akun tersebut bisa memenangkan argumentasi yang telah dilakukannya dan mengendalikan orang lain.

Dalam komentar pada thread ini peneliti dikejutkan dengan ditemukannya banyak katakata makian dan kasar yang dilontarkan oleh akun pria. Kata-kata kasar dan makian dibagi menjadi 2 kelompok, yang pertama kata-kata makian kepada pelaku pemerasan (dominan) dan yang kedua kelompok yang memaki korban pemerasan dan pelecehan seksualnya.

Pada kelompok pertama yang menggunakan kata-kata makian kepada pelaku dapat dlihat oleh tweet yang di lakukan oleh beberapa akun berikut ini: pertama tweet dari akun@StBuari yang di tweet pada tanggal 21 Spt 2020 "Dokter kurang ajar potong saja kem*****nya.”Kedua dari akun@mati_rasa13 ditweet pada tanggal 19 September 2020 yang berisi "Dongo bgt ya itu orang, hasil kuliah jalur orang dalem kali ya. ko bisa bisaan dia jadi dokter" dan yang ketiga adalah dari akun @andykopet yang di tweet pada tanggal 19 September 2020 yang berisi "sudah saya dm mbak orangnya, semoga tepat sasaran (isi dm nya : BANG*** LUUU ANJ*** BANGEETTT, DASAR MANT** MANUSIA KON***)"

Pada kelompok kedua, yaitu kelompok yang menggunakan kata-kata kasar dan makian yang menyalahkan korban ada pada tweet yang di katakan oleh akun @sihol72 pada tanggal 18 September 2020 berikut ini : "Wah perjalanan anda sdh keluar negeri tentu wawasan dan pengetahuan serta keberanian anda sdh kuat tp koq ga melawan ketika digituin itu namanya Bodoh". Dalam mengutip beberapa tweet kasar dan makian tersebut, penulis telah melakukan beberapa sensor.

Kata-kata kasar, dan makian sangat erat hubungannya dengan bahasa sehari-hari pria. Dari kedua kelompok tersebut dapat terlihat bahwa pria cenderung menggunakan kata-kata kasar kepada semua kalangan, baik pria sebagai pelaku pemerasan dan pelecehan seksual, maupun kepada wanita yang dalam hal ini berperan sebagai korban dari pemerasan dan pelecehan seksual. Sangat berbeda dengan bahasa wanita yang penuh kesantunan.

Tetapi tidak bisa disimpulkan bahwa pria dominan menggunakan kata-kata kasar, banyak juga pria yang menggunakan kata-kata sopan dan halus seperti yang ditunjukkan dalam tweet dari akun seorang influencer terkenal di Indonesia yaitu@tirta_hudhi yang di tweet pada tanggal 18 September 2020 sebagai berikut : "Semoga pelaku cepet tertangkap dan diproses sesuai aturan, Ini kami bantu cek di KKI (konsil kedokteran Indonesia) ga ada nama itu kak Kalo boleh tau selama di tkp, inget baju / memakai rompi / seragam apakah? Suwun kak"

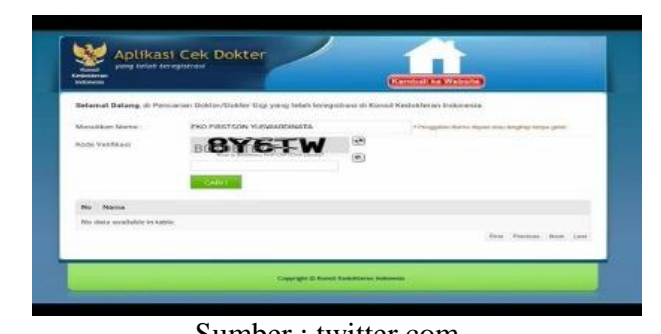

Gambar 10. Bukti yang di upload akun @ tirta-hudhi

Dari melihat banyaknya komentar pada thread tersebut, dapat terlihat bahwa pria dan wanita pada dasarnya juga memiliki satu kesamaan yaitu bahwa oknum dokter tersebut telah dengan sengaja merubah hasil rapid test dari positif menjadi negatif agar mendapatkan keuntungan dari hal tersebut dan korban dari oknum tersebut telah banyak. Hal itu ditunjukkan dengan pengakuan beberapa orang yang mengatakan bahwa sebelumnya telah membayar sejumlah uang kepada oknum dokter tersebut agar bisa merubah hasil rapid dari positif reaktif menjadi negatif. Hal ini menunjukkan bahwa pria dan wanita memiliki kesamaan dalam menarik kesimpulan walaupun dengan gaya bahasa pria dan wanita yang berbeda dalam beberapa hal saat menyampaikan pemikirannya.

Kemampuan dalam memahami sudut pandang orang lain sangat penting dalam berkomunikasi. Agar mampu menerima pesan secara tepat, seseorang perlu mengetahui sudut pandang pengirim pesan. Meminjam istilahJohnson (1981), dalam berkomunikasi sebaiknya seseorang membiasakan diri mencobaberdiri 'beralaskan sepatu' lawan 
komunikasi, menggenakan kacamatanya. Dengan demikian, komunikasi yang terjalin dengan orang lain akan menjadi lancar dan efektik. Bila dalam proses komunikasi masingmasing pihak bertahan pada keadaan diri masing-masing,maka proses komunikasi tidak akan berjalan secara efektif. (Harapan, Edi dan Ahmad, 2014 ; 53). Hal itupun terjadi dalam bahasa wanita dan pria. Perbedaan-perbedaan tersebut jangan sampai menjadi proses penghalang dalam berkomunikasi yang menyebabkan komunikasi tidak berjalan secara efektif dan menimbilkan perasaan saling mencurigai diantara para pihak.

\section{CONCLUSIONS}

Hasil pada penelitian ini ditemukan banyak perbedaan diantara pria dan wanita. Tedapat perbedaan antara bahasa wanita dengan bahasa pria. Saat terlibat dalam percakapan, sering kali wanita menggunakan kata-kata yang menunjukan ekspresinya dan menjalin hubungan kedekatan dengan lawan bicaranya. Interupsi wanita bukan untuk mengendalikan seperti yang dilakukan oleh pria, bukan menantang atau mengancam lawan bicara, walaupun mungkin hal tersebut mungkin terjadi namun cenderung untuk menekankan dan menegaskan pembicara. Dalam konteks ini kata-kata yang diucapkan wanita kurang lugas dari pada apa yang diucapkan pria.

Wanita juga jarang menggunakan tutur bahasa kasar dan umpatan Bahasa wanita cenderung menekankan kepatuhan, persetujuan, atau kepercayaan kepada pendengar. Penggunaan bahasa yang halus dan sopan merupakan salah satu ciri dari bahasa yang digunakan wanita. Yang sangat jelas terlihat pada bahawa wanita adalah wanita seringkali melibatkan perasaan dalam bahasa dan katakata yang mereka gunakan. Wanita sangat menjaga perasaan orang yang menjadi lawan bicaranya. Wanita mengutamakan rasa kasih sayang, hubungan pertalian untuk berbicara agar lawan bicaranya percaya dengan apa yang dikatakan dan bisa menyamakan persepsi.

Sementara itu, pria menggunakan lebih bayak pembicaraan instrumental (untuk mempengaruhi dan mengendalikan orang lain), melaporkan informasi, memecahkan masalah, dan menyelesaikan permasalahan yang dihadapi melalui pertukaran informasi. Pria lebih banyak menggunakan kata-kata kasar dari pada wanita. Gaya bahasa pria cenderung tegas dan 'blakblakan' dalam menyampaikan pemikiran, pendapat dan argumentasinya. Yang paling mencolok dari bahasa pria disini adalah bahasa pria yang mengadopsi gaya gaya yang lebih kompetitif dalam suatu percakapan.

Selain perbedaan dalam beberapa hal tersebut, ada persamaan diantara wanita dan pria dalam menarik kesimpulan walaupun dengan gaya bahasa pria dan wanita yang berbeda dalam hal menyampaikan pemikirannya. Penelitian ini pada dasarnya bukan untuk melihat apakah bahasa wanita lebih baik daripada bahasa pria, bukan juga sebaliknya bahasa pria lebih baik dari pada bahasa wanita. Yang dilihat dari penelitian ini adalah keragaman yang ada diantara bahasa wanita dan pria. Faktor-faktor seperti sosial dan ekonomi seringkali mendorong seseorang untuk menggunakan bahasa sesuai dengan peran dan kondisi diri kita. Yang dibutuhkan pria dan wanita saat ini adalah keterampilan dalam menggunakan bahasa dan menyampaikan pesan kepada komunikan, karena kerugian akan muncul ketika wanita atau pria tidak terampil menggunakan gaya bahasa dari suatu gaya ke gaya yang lainnya sesuai dengan situasi dan kondisi.

\section{REFERENCES}

Amri, Z. (2009). Perbedaan Bahasa Siswa LakiLaki Dan Siswa Perempuan: Sebuah Studi Kasus Di Kelas V Sdn 09 Air Tawar Barat Padang Sumatera Barat. Lingua Didaktika: Jurnal Bahasa Dan Pembelajaran Bahasa, $3(1)$, 96. https://doi.org/10.24036/ld.v3i1.7371

Hanana, A., Anindya, A., \& Elian, N. (2020). Transformasi Media Youtube dan Televisi (Analisis Fungsi danKonsimsi Media Youtube dan Televisi di Kota Padang). Jurnal Ranah Komunikasi, 4(2), 186-194.

Hidayati, N. N. (2016). Bahasa dan Gender: Kajian Karakteristik Kebahasaan Laki-Laki dan Perempuan dalam Film Anak. $A L$ HIKMAH Jurnal Studi Keislaman, 6(1), 932.

Littlejohn, S. W., \& Foss, K. A. (2011). Teori Komunikasi, Theories of Human Communication. Jakarta: Selemba Humanika.

Mayasari, A. (2019). Kamu Perlu Tahu! 13 
Bahasa Gaul yang Cuma Dimengerti Anak Twitter. Retrieved September 28, 2020, from Detik.com website: https://wolipop.detik.com/entertainmentnews/d-4600251/kamu-perlu-tahu-13bahasa-gaul-yang-cuma-dimengerti-anaktwitter

McQuail, D. (2011). Teori Komunikasi Massa Mc Quail, Buku 1 Edisi 6. Jagakarsa Jakarta: Selemba Humanika.

Mulyana, D. (2010). Ilmu Komunikasi, Suatu Pengantar. Bandung: Remaja Rosdakarya.

Naibaho, R. M. (2016). Opini Pemuka Masyarakat Terhadap Gaya Komunikasi Pemimpin (Studi Kasus Gaya Komunikasi Verbal dan Non Verbal Bupati Pakpak Bharat Remigo Yolando Berutu) (Universitas Sumatera Utara). Retrieved from http://repositori.usu.ac.id/bitstream/handle/1 23456789/16992/127045013.pdf?sequence $=1$

Rakhmat, J. (2018). Psikologi Komunikasi, Edisi Revisi. Bandung: Remaja Rosdakarya.

Rakhmat, J., \& Ibrahim, S. (2017). Metode Penelitian Komunikasi. Bandung: Simbiosa Rakatama Media.

Ruben, B. D., \& Stewart, L. P. (2013). Komunikasi dan Perilaku Manusia. Depok: Rajawali Pers.

Utami, T. M., \& Hermanu, D. H. (2020). Pengaruh Komunikasi Word of Mouth Terhadap Brand Awarness Konsumen ECommerce Sorabel. Jurnal Ranah Komunikasi, 4(2), 195-204.

Yunita, S. R., Udasmoro, W., Budaya, F. I., Mada, U. G., Nusantara, J., \& Tunggal, C. (2011). Gender dan identitas dalam sastra di mata remaja Gender and identity of teenager in the literature from teens perspective. 94-105.

Zulkarnain, S. I., \& Fitriani, N. (2018). Perbedaan Gaya Bahasa Laki-Laki dan Perempuan Pada Penutur Bahasa Indonesia dan Aceh. Gender Quality: International Journal of Child \& Gender Student, 4(1), 159-172. 